\title{
Apoptosis of human endothelial cells is accompanied by proteolytic processing of latent TGF- $\beta$ binding proteins and activation of TGF- $\beta$
}

\author{
VT Solovyan ${ }^{\star, 1}$ and J Keski-Oja ${ }^{1}$ \\ ${ }^{1}$ Departments of Pathology and Virology, Haartman Institute, University of \\ Helsinki, Biomedicum Helsinki and Helsinki University Hospital, FIN-00014 \\ Helsinki, Finland \\ * Corresponding author: V Solovyan, Cell Biology, Biomedicum Helsinki, \\ Haartmaninkatu 8, Helsinki FIN-00014, Finland. Tel: + 3589191 25566; \\ Fax: + 3589191 25573; E-mail : Victor.Solovyan@uku.fi
}

Received 03.1.05; revised 03.2.05; accepted 03.2.05; published online 08.4.05 Edited by G Melino

\begin{abstract}
Transforming growth factors $\beta$ (TGF- $\beta$ s) are multifunctional cytokines that modulate cell growth, differentiation and apoptosis. Numerous effects initiated by TGF- $\beta$ s in vitro have been described, but the role of TGF- $\beta$ targeting and activation under physiological conditions has gained very little attention and understanding. We report here that apoptosis of human umbilical vein endothelial cells (HUVECs) is accompanied by release of truncated large latent TGF- $\beta$ complexes from the pericellular matrix followed by activation of TGF- $\beta$. The activation of TGF- $\beta$ during apoptosis was accompanied by enhanced secretion of $\beta 1$-LAP protein, and apoptotic HUVECs acquired the capacity to induce the release of latent TGF- $\beta$ binding proteins (LTBPs) from extracellular matrices. Activated TGF- $\beta$, in turn, attenuated apoptotic death of HUVECs. Current results indicate that the activation of TGF- $\beta$ accompanies the apoptosis of HUVECs, and may play a protective feedback role against apoptotic cell death. The results suggest a role for TGF- $\beta$ as a putative extracellular modulator of apoptosis.

Cell Death and Differentiation (2005) 12, 815-826.

doi:10.1038/sj.cdd. 4401618

Published online 8 April 2005
\end{abstract}

Keywords: programmed cell death; endothelial cell; extracellular matrix; LTBP; cell-matrix interaction; anoikis; staurosporine

Abbreviations: FACS, fluorescence-activated cell sorting; HUVEC, human umbilical vein endothelial cell; LAP, latencyassociated protein; LL-TGF- $\beta$, large latent TGF- $\beta$; LTBP, latent TGF- $\beta$-binding protein; MT-MMP, membrane-type matrix metalloprotease; Mv1Lu cell, mink lung epithelial cell; SL-TGF- $\beta$, small latent TGF- $\beta$; TGF- $\beta$, transforming growth factor $\beta$; $\beta 1$-LAP, LAP of TGF- $\beta 1$

\section{Introduction}

Apoptosis or programmed cell death plays an important role in the development of multicellular organisms and in the maintainance of tissue homeostasis. ${ }^{1}$ Activation of caspases, a unique family of cysteine-asparagine proteases, ${ }^{2}$ extensive caspase-mediated proteolysis of a number of cellular proteins, and an ordered disintegration of nuclear DNA into oligonucleosome-sized DNA fragments ${ }^{1,3}$ are considered as essential manifestations of the apoptotic cell death.

Apoptosis of endothelial cells is a widely studied phenomenon, which involves similar mechanisms as those described above. ${ }^{4-7}$ Endothelial cell apoptosis is involved in several vascular diseases, ${ }^{8}$ and plays a role in angiogenesis, ${ }^{9}$ a critical process in wound-healing, inflammation, cancer development, and embryogenesis. While the apoptotic executioner machinery of endothelial cells is the same one as in other models of apoptosis, the dependence of endothelial cells on a variety of growth factors implies an important role for cytokines in the regulation of endothelial apoptotic response.

Transforming growth factors $-\beta$ (TGF- $\beta$ s) are multipotent cytokines, which modulate a variety of cell functions including cell growth, differentiation, and apoptosis. ${ }^{10,11}$ All mammalian TGF- $\beta$ s (TGF- $\beta 1$, TGF- $\beta 2$, and TGF- $\beta 3$ ) are, in general, synthesized as inactive, latent forms. Latency is conferred by noncovalent association of the $\mathrm{N}$-terminal part of the pro-TGF$\beta$ peptide (also known as the latency-associated protein, LAP) with the mature TGF- $\beta$ after processing of the propeptide by furin-type enzymes. ${ }^{11}$ TGF- $\beta$-LAP complex, also known as small latent TGF- $\beta$ (SL-TGF- $\beta$ ), is further assembled into the large latent complex (LL-TGF- $\beta$ ) by the formation of the disulfide linkages between LAP and the latent-TGF- $\beta$-binding proteins (LTBPS). ${ }^{12}$ LTBPs (LTBP-1, -3, and -4) confer efficient secretion and subsequent deposition of the latent TGF- $\beta$ s to the extracellular matrix (ECM) due to the specific interactions of LTBPs with the ECM components. ${ }^{10,13}$ Thus, the formation of $\sim 290 \mathrm{kDa}$ LL-TGF- $\beta$ complex (TGF- $\beta$, its propeptide LAP, and LTBP), anchored to the ECM, ${ }^{14}$ (see also Figure 2) represents the predominant way of storage of the latent TGF- $\beta$.

Activation of TGF- $\beta$ implies the release of the mature cytokine from the LL-TGF- $\beta$ complex. A variety of agents and treatments capable of activating latent TGF- $\beta$ have been described. Heat, acidic $\mathrm{pH}$, chaotropic agents, and reactive oxygen species potentiate the release of the active TGF- $\beta$ in vitro via mechanisms involving the disruption of the TGF- $\beta$ LAP interaction. ${ }^{10,15}$ The activation of TGF- $\beta$ by the matricellular protein trombospondin- $1,{ }^{16}$ as well as by the integrin $\alpha_{v} \beta_{6}{ }^{17,18}$ seem to proceed via similar mechanisms. In addition, a number of proteases including plasmin, ${ }^{19,20}$ matrix metalloproteinases MMP-3, -9, and MT1-MMP, ${ }^{21,22}$ as well as exocytosed cathepsin $\mathrm{B}^{23}$ have been identified as activators of latent TGF- $\beta$, at least in vitro.

Despite the obvious progress in the understanding of the mechanisms of TGF- $\beta$ activation, the physiological conditions leading to its activation have been elucidated rather slowly. 
The current work was carried out to understand the interrelationships between endothelial cell apoptosis and the activation of latent TGF- $\beta$. We analysed TGF- $\beta$ activation in human umbilical vein endothelial cells (HUVECs) undergoing apoptosis induced by staurosporine or by the prevention of cell adhesion (anoikis). We found that regardless of the inducer, the apoptosis of HUVECs was constantly accompanied by proteolytic processing of LL-TGF- $\beta$ complex into soluble truncated form and phosphorylation of Smad2, a key mediator of TGF- $\beta$ signalling. Activated TGF- $\beta$, in turn, was able to modulate the apoptotic response of HUVECs leading to attenuation of cell death.

\section{Results}

\section{Activation of TGF- $\beta$ during staurosporine-induced apoptosis of HUVECs}

To elucidate whether the activation of TGF- $\beta$ accompanies apoptosis, we analysed the TGF- $\beta$ activation response in HUVECs induced to undergo apoptosis by staurosporine. ${ }^{7}$ Incubation of HUVECs with staurosporine in serum-free medium resulted in the activation of caspases, indicative of the initiation of apoptosis (Figure 1a). Staurosporine-induced apoptosis of HUVECs was accompanied by the phosphorylation of Smad2, a key regulator of TGF- $\beta$ signalling (Figure 1b), suggesting the activation of TGF- $\beta$. Neither caspase activation nor obvious Smad phosphorylation were detected in control HUVECs incubated for the same period of time in serum-free medium without staurosporine (Figure 1a and b), indicating the relevance of TGF- $\beta$ activation to staurosporineinduced apoptosis.

Activation of TGF- $\beta$ during staurosporine-induced apoptosis of HUVECs was accompanied by the release of $\sim 200$ and $\sim 140 \mathrm{kDa}$ truncated forms of LL-TGF- $\beta$ into their conditioned medium (Figure $2 b$ ), suggesting a role for LTBP proteolysis in the activation of TGF- $\beta$. Indeed, the accumulation of truncated forms of LTBP-1 into the conditioned medium was observed in parallel with the accumulation of truncated LL-TGF- $\beta$ (Figure 2c). Interestingly, only a small proportion of truncated LTBP-1 was observed in the form of $\sim 120 \mathrm{kDa}$, a size that corresponds to the truncated LTBP- 1 free of LAP, ${ }^{14}$ suggesting the truncation of LTBP-1 in association with SL-TGF- $\beta$ complex (Figure 2c). Accumulation of truncated LTBP-1 into the conditioned medium of staurosporine-treated cells was almost completely prevented by the serine protease inhibitor AEBSF, a nontoxic analogue of PMSF. Interestingly, no obvious inhibitory effect of AEBSF was observed on the accumulation of $\sim 140 \mathrm{kDa}$ truncated LL-TGF- $\beta$ (Figure $2 \mathrm{c}$ ). These results are suggestive of proteolytic processing (truncation) of the other isoforms, namely LTBP-3 or LTBP4, during staurosporine-induced apoptosis of HUVECs. Interestingly, recombinant TGF- $\beta 1$, while being capable of enhancing the phosphorylation status of Smad proteins, resembled the effect of staurosporine on the processing of LL-TGF- $\beta$ complex. Both control and staurosporine-treated cells showed enhanced accumulation of truncated LL-TGF- $\beta$ into the culture medium in the presence of recombinant TGF- $\beta 1$ (Figure $2 d$ ). The results are suggestive of a positive a

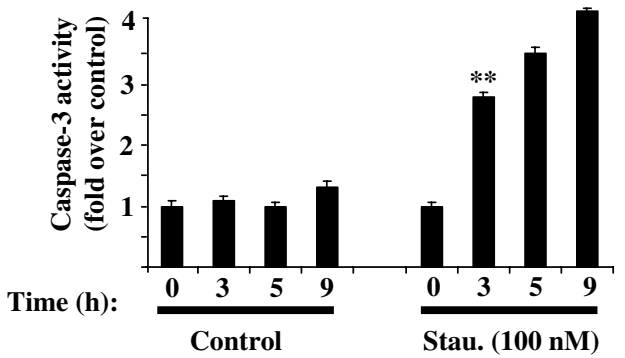

b

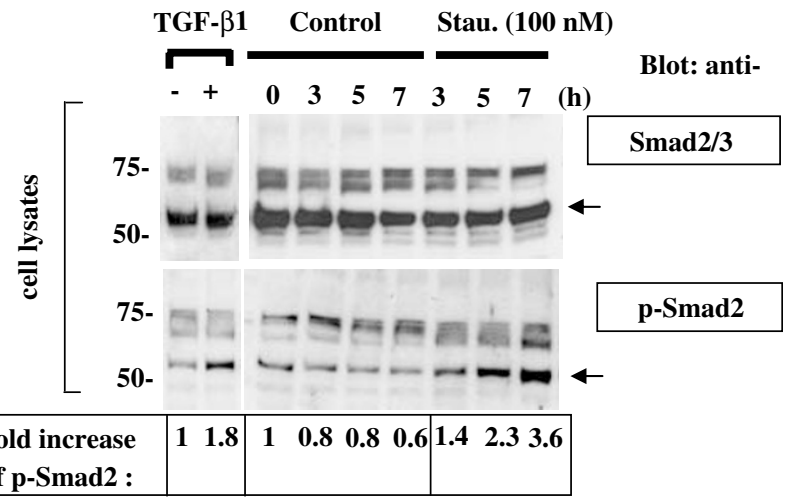

Figure 1 Activation of TGF- $\beta$ during staurosporine-induced apoptosis of HUVECs. Cells were incubated in serum-free medium either alone (Control) or with $100 \mathrm{nM}$ staurosporine (Stau.) After the indicated periods of time, the cells and conditioned medium were harvested. (a) Analysis of cell lysates for caspase3 activity. Values are means \pm S.D., $n=3,{ }^{\star \star} P<0.01$ as compared to the 'stau. $0 \mathrm{~h}$ ' group. (b) Analysis of Smad phosphorylation. Total Smad2/3 proteins (upper panel) and phosphorylated Smad2 (lower panel) are indicated by arrows. The positive control of Smad phosphorylation (left part of the panel) was from HUVECs treated with TGF- $\beta 1(1 \mathrm{ng} / \mathrm{ml})$ in serum free conditions for $2 \mathrm{~h}$. The relative levels of Smad phosphorylation are shown at the bottom. Note that staurosporine induced casapse-3 activation in parallel with phosphorylation of Smad2, indicative of activation of TGF- $\beta$

feedback loop, which could operate between TGF- $\beta$ activation and the accumulation of truncated LL-TGF- $\beta$ into the medium.

To analyse the relevance of the accumulation of truncated LL-TGF- $\beta$ and phosphorylation of Smad2 for staurosporineinduced apoptosis, a caspase inhibition assay was carried out. We observed that both of these events were partially suppressed by the pan-caspase inhibitor, BOC-D-fmk (Figure 3). BOC-D-fmk did not abrogate the phosphorylation of Smad2, but markedly enhanced the decline of its phosphorylated status during staurosporine treatment (Figure 3b). The suppressive effect of the caspase inhibitor, both on the accumulation of LL-TGF- $\beta$ and Smad phosphorylation, provides further evidence for the relevance of TGF- $\beta$ activation to apoptosis.

\section{Secretion of LL-TGF- $\beta$ complex from the cells and release from the ECM are two means for generation of active TGF- $\beta$ during apoptosis}

As staurosporine-induced apoptosis of HUVECs was accompanied by the accumulation of truncated LL-TGF- $\beta$ into the 


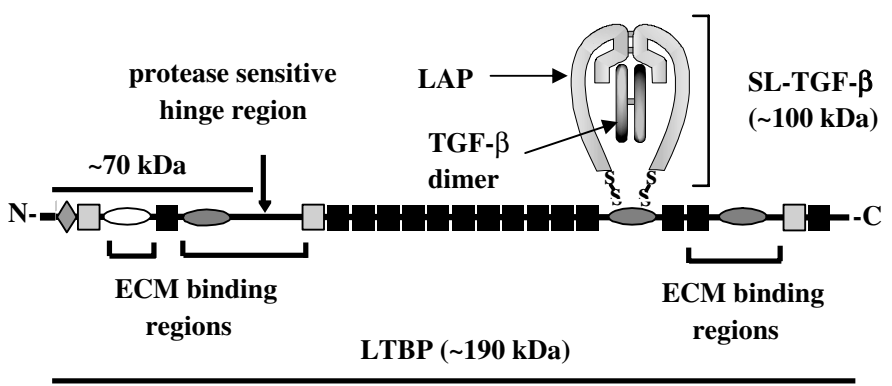

b

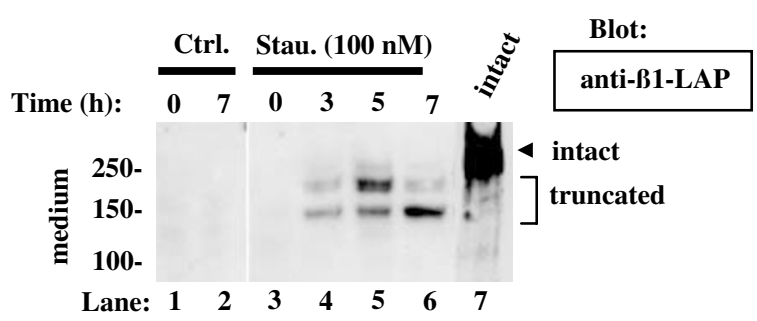

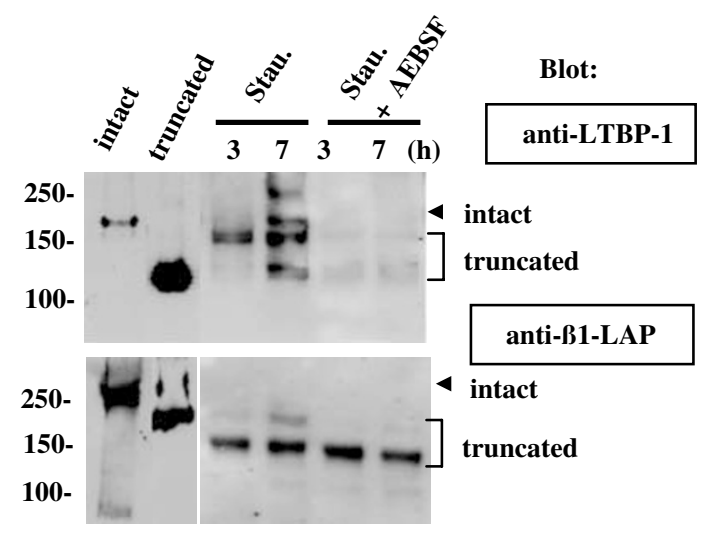

d

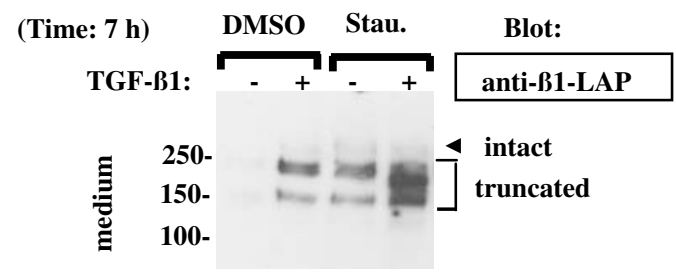

Figure 2 Activation of TGF- $\beta$ during staurosporine-induced apoptosis is associated with truncation of LL-TGF- $\beta$ complex. Cells were incubated in serum-free medium either alone (Control) or with $100 \mathrm{nM}$ staurosporine (Stau.) for $0-7 \mathrm{~h}$. After indicated periods of time, conditioned media were harvested and analysed for secreted polypeptides. (a) Scheme of LL-TGF- $\beta$ structure. Shaded boxes represent different structural domains of LTBP $\left(8-C y s\right.$ repeats, $\mathrm{Ca}^{2+}-$ binding and non-Ca ${ }^{2+} \mathrm{EGF}$-like repeats, hybrid domain; see Koli et al. ${ }^{15}$ for details). Protease sensitive hinge region and ECM binding regions are indicated. Molecular weights of small latent TGF- $\beta$ (SLTGF- $\beta$ ), full-length LTBP, and LTBP fragment after proteolytic processing within hinge region are given. (b) Analysis of secreted polypeptides. Polypeptides released into the medium were immunodetected by antibodies against $\beta 1$-LAP. Migration of intact LL-TGF- $\beta 1$ solubilized from the ECM of nonapoptotic lung fibroblasts is shown (lane 7, arrowhead). Truncated LL-TGF- $\beta$ is marked by brackets, and the migration of intact form by an arrowhead. (c) Inhibitory effect of the serine protease inhibitor, AEBSF, on the release of truncated LTBP-1 and LL-TGF- $\beta 1$ complex. Cells were treated with $100 \mathrm{nM}$ staurosporine (Stau.) for $3-7 \mathrm{~h}$ either alone or with $1 \mathrm{mM}$ AEBSF. The released polypeptides were immunodetected by antibodies against $\beta 1$-LAP or LTBP-1 as indicated. The migration of the control polypeptides, LTBP-1 and LL-TGF- $\beta$, both intact (upper) and plasmin-truncated (lower) are shown on the left. Control polypeptides were solubilized from the ECM of the nonapoptotic lung fibroblasts. Truncated LL-TGF- $\beta$ and LTBP-1 are marked by brackets, and the intact forms by arrowheads. Note that AEBSF almost completely prevented the truncation of LTBP-1, but was not very effective in inhibiting the LL-TGF- $\beta 1$ truncation (lower part; anti- $\beta 1$-LAP), suggestive of the truncation of the other LTBP isoforms. (d) TGF- $\beta 1$ imitates the effect of staurosporine by enhancing the accumulation of truncated LL-TGF- $\beta$ complex. Control and staurosporine-treated cells (100 nM) were treated with TGF- $\beta 1$ $(1 \mathrm{ng} / \mathrm{ml})$ for $7 \mathrm{~h}$ followed by immunodetection of the secreted polypeptides by antibodies against $\beta 1$-LAP. Truncated LL-TGF- $\beta$ is marked by brackets, and the intact form by an arrowhead. Note that while staurosporine-induced apoptosis of HUVECs was associated with the accumulation of truncated LL-TGF- $\beta$ into the conditioned medium, exogenous TGF- $\beta 1$ enhanced the release of truncated LL-TGF- $\beta$ as well

conditioned medium, and because the ECM is a major storage compartment for the latent TGF- $\beta \mathrm{s},{ }^{14}$ we investigated whether apoptosis favouring conditions could promote the release of LTBPs from the ECM as a putative step in the activation of TGF- $\beta$. Immunodetection analysis after plasmin digestion revealed that the ECM isolated from the staurosporine-treated HUVECs was almost quantitatively depleted from LTBP-1 (Figure 4a). Accordingly, incubation of the ECMs, isolated from human lung fibroblast cultures, with the conditioned medium from staurosporine-treated HUVECs induced the release of truncated LTBP-1 fragments into the medium (Figure 4b). Release of truncated LTBP-1 from the ECM was specifically initiated by the conditioned medium from apoptotic cells. Neither the plain control medium (fresh serum-free medium supplemented with staurosporine; Figure $4 \mathrm{~b}$, lane $0-h$ ) nor the control conditioned medium (serum-free medium without staurosporine, harvested after $7 \mathrm{~h}$ incubation with HUVECs; Figure $4 \mathrm{~b}$, lane $7 \mathrm{~h}$ ctrl. medium') was able to induce the release the LTBP proteins from the ECM preparations. Interestingly, essentially a similar pattern of LTBP-1 fragments was released from the ECM by conditioned medium from apoptotic cells as by plasmin (Figure $4 \mathrm{~b}$, see also Taipale et al. ${ }^{24}$ ). The results suggest that certain components of the conditioned medium from apoptotic cells are able to induce proteolytic processing of $\mathrm{ECM}$-associated LL-TGF- $\beta$, evidently at the protease sensitive hinge region, in a manner similar to that induced by plasmin. $^{14,24}$

Analysis of the cell lysates revealed that the total amount of $\beta 1$-LAP protein, either free or in complex with LTBPs (LLTGF- $\beta 1$ ), was substantially increased in staurosporine-treated HUVECs (Figure 4c). These results suggest that apoptotic cells per se can be the source of TGF- $\beta$ activation during apoptosis. To further elucidate this, we investigated the turnover of LL-TGF- $\beta$ during apoptosis of HUVECs, induced by another mechanism, namely by the prevention of cell 
a

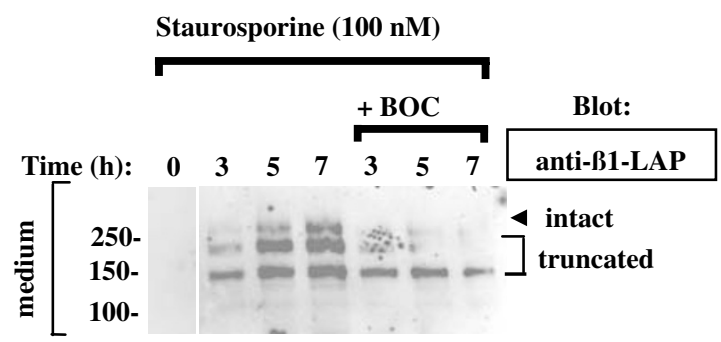

b

Staurosporine $(100 \mathrm{nM})$

(1)

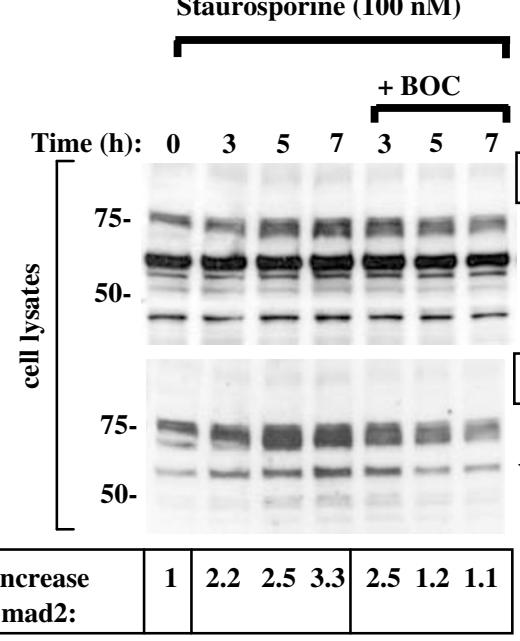

Figure 3 Pan-caspase inhibitor BOC-D-fmk (BOC) inhibits both truncation of LL-TGF- $\beta$ complex and Smad phosphorylation. The cells were treated with staurosporine and the pan-caspase inhibitor, BOC-D-fmk (BOC, $75 \mu \mathrm{M})$. The polypeptides accumulated into the medium (a) and polypeptides of the cell lysates (b) were immunodetected by antibodies against TGF- $\beta 1$-LAP, Smad2/3 or $p$-Smad as indicated. Both intact form and truncated fragments of LL-TGF- $\beta$ are indicated. Phosphorylated Smad2 and total Smad2/3 proteins are indicated by arrows. The relative levels of phosphorylation are given at the bottom. Note that BOC-D-fmk inhibited the processing of LL-TGF- $\beta$ complex and decreased the phosphorylation status of Smad during staurosporine-induced apoptosis. Total amounts of Smad 2/3 proteins illustrate comparable levels (Figure $3 \mathrm{~b}$, upper part)

adhesion (anoikis). For this aim the cells were detached by trypsinization and incubated in fresh culture plates covered with agarose, thus excluding ECM as a source for activated TGF- $\beta$. We found that incubation of HUVECs under these conditions induced the activation of the initiator caspase-8 and execution caspase-3 in the cells, indicative of the induction of apoptosis (Figure 5a). Accordingly, the attachment-impaired apoptosis was associated with phosphorylation of Smad2 (Figure $5 \mathrm{~b}$ ), suggesting the activation of TGF- $\beta$ during anoikis of HUVECs. Despite the lack of ECM in this apoptosis model, anoikis of HUVECs was still accompanied by the accumulation of truncated LL-TGF- $\beta$ fragments into the conditioned medium (Figure 5c), suggestive of the secretion and subsequent truncation of LL-TGF- $\beta$ from the apoptotic (anoikis) cells. Similarly to staurosporine-induced apoptosis, the accumulation of truncated LL-TGF- $\beta$ into the conditioned medium from the anoikis HUVECs was inhibited by the pancaspase inhibitor, BOC-D-fmk (Figure $5 \mathrm{~d}$ ), further suggesting a common feature of TGF- $\beta$ activation in different models of apoptosis.
Current data indicate that different models of HUVEC apoptosis are invariably accompanied by the proteolytic processing and activation of TGF- $\beta$. The release of TGF- $\beta$ from the ECM and its direct secretion from the cells seem to represent two different pools of activated TGF- $\beta$ during apoptosis.

\section{TGF- $\beta 1$ is predominantly activated during HUVEC apoptosis}

To further elucidate the relationships between apoptosis and activation of TGF- $\beta$, we used mink lung epithelial cells (Mv1Lu) stably transfected with luciferase reporter gene under TGF- $\beta$ - sensitive promoter. ${ }^{25}$ The activation of TGF- $\beta$ in these cells can be monitored by measuring luciferase activity.

We found that the conditioned medium from staurosporinetreated HUVECs induced 2.5-3-fold increase in luciferase but not caspase- 3 activity of target Mv1Lu as rapidly as within $3 \mathrm{~h}$ of incubation, an effect comparable with that obtained by $1 \mathrm{ng} /$ $\mathrm{ml}$ TGF- $\beta 1$ for the same period of incubation (Figure 6a). Interestingly, staurosporine alone induced also luciferase activity in target Mv1Lu to the similar level. However, in strict contrast to the conditioned medium from staurosporinetreated HUVECs ('apo-med.'), staurosporine alone induced luciferase activity in target Mv1Lu cells in association with caspase-3 activation (Figure 6a), indicative of the induction of Mv1Lu cell apoptosis. Luciferase activity induced by conditioned medium from staurosporine-treated HUVECs or by staurosporine alone was completely prevented by cycloheximide, indicating that the effect was not due to self-oxidation of the luciferase substrate (Figure 6b). Interestingly, luciferase activity induced by conditioned medium from staurosporinetreated HUVECs was almost completely suppressed by antiTGF- $\beta 1$, but not by anti-TGF- $\beta 2$ or $-\beta 3$ antibodies (Figure $6 \mathrm{~b}$ ). None of the antibodies was effective in suppressing luciferase activity induced by staurosporine alone (Figure 6b). Whether this was due to the inability of antibodies against human TGF- $\beta 1$ to recognize mink TGF- $\beta 1$ or whether TGF- $\beta 2$ and $-\beta 3$ were activated in situ in the pericellular space during staurosporine-induced apoptosis of Mv1Lu cells, remains unclear at present. The current results indicate that not only apoptosis of HUVECs but also apoptosis of Mv1Lu cells is accompanied by the activation of TGF- $\beta$, and also suggest that TGF- $\beta 1$ is predominantly activated during HUVEC apoptosis.

The conditioned medium from anoikis HUVECs initiated also luciferase activity in target Mv1Lu cells without concomitant caspase-3 activation (Figure $6 \mathrm{c}$ ), suggesting the presence of activated TGF- $\beta$ in the medium. Similarly to the conditioned medium from staurosporine-treated cells, the induction of luciferase activity by the conditioned medium from anoikis HUVECs ('apo-medium') was almost completely suppressed by anti-TGF- $\beta 1$ antibody (Figure $6 \mathrm{c}$ ). Interestingly, while the conditioned medium from anoikis HUVECs ('apo-medium') induced luciferase activity in target Mv1Lu cells without concomitant caspase activation (Figure 6c), the same medium induced the activation of caspase-3 in target HUVECs (Figure 6d). Regardless of whether the activation of 
a

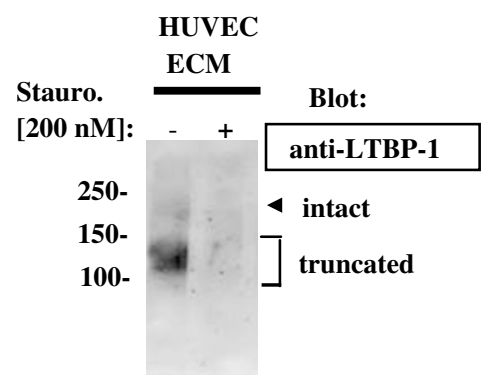

b Substrate: lung fibroblast ECM

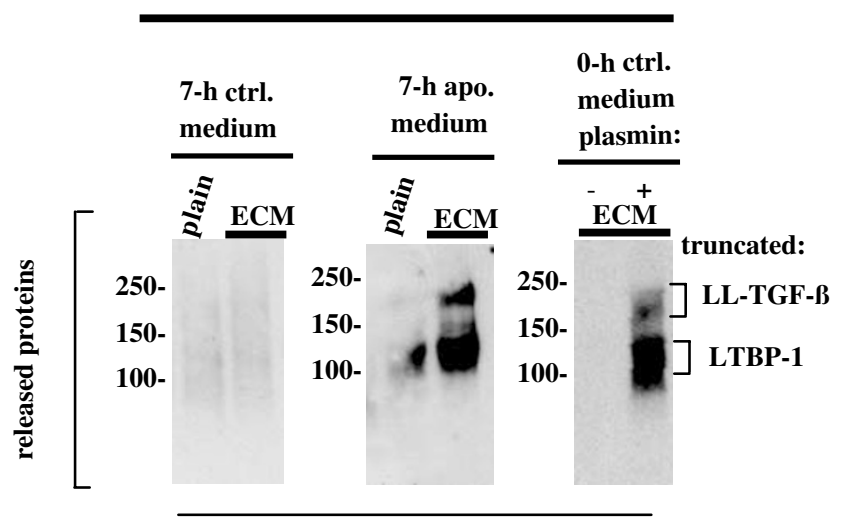

Blot: anti-LTBP-1

C

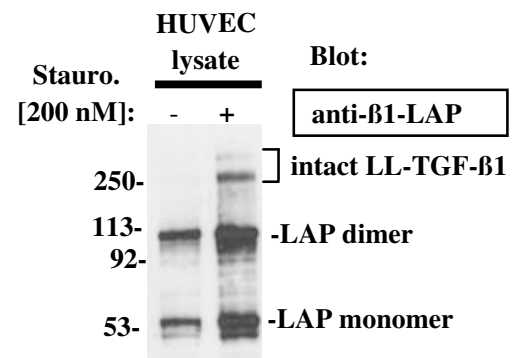

Figure 4 Release of LL-TGF- $\beta$ from the extracellular matrix (ECM) and its secretion from the cells as two sources for generation of active TGF- $\beta$ during staurosporine-induced apoptosis of HUVECs. Cells were incubated with $200 \mathrm{nM}$ staurosporine in serum-free medium for $7 \mathrm{~h}$ to induce apoptosis. (a) Extracellular matrices from control and staurosporine-treated cells were isolated ${ }^{48}$ and treated with plasmin $(0.1 \mathrm{U})$ for $1 \mathrm{~h} .{ }^{16}$ Soluble polypeptides were then separated by SDSPAGE and immunodetected by antibodies against LTBP-1. Truncated LTBP-1 is marked by brackets, and the intact form by arrowhead. Note that ECM from staurosporine-treated cells was markedly depleted from LTBP-1 protein. (b) Isolated fibroblast $\mathrm{ECMs}$ were incubated at $37^{\circ} \mathrm{C}$ for $2 \mathrm{~h}$ with conditioned medium from apoptotic HUVECs after $7 \mathrm{~h}$ incubation with staurosporine ( $7 \mathrm{~h}$ apo. medium'), with control conditioned medium harvested after $7 \mathrm{~h}$ of cell incubation without staurosporine ('7-h ctrl. medium'), or with fresh serum-free medium supplemented with staurosporine ('0-h ctrl. medium'). As a control, the same media were incubated at $37^{\circ} \mathrm{C}$ for $2 \mathrm{~h}$ without ECM (plain medium). Plasmindependent release of LTBP-1 from the ECM (positive control) is shown in rightmost lane. Note that conditioned medium from staurosporine-treated cells induced the release of LTBP-1 from ECM, with the pattern of cleavage products comparable with that obtained by plasmin. (c) Cell lysates of staurosporinetreated cells were analysed for the levels of TGF- $\beta 1$-LAP. Positions of $\beta 1$-LAP, free of LTBP and in complex with LTBP (full-length LL-TGF- $\beta 1$ ) are indicated. Note that the level of TGF- $\beta 1$ was increased in staurosporine-treated cells as detected by anti- $\beta 1$-LAP antibodies caspase-3 was induced by proapoptotic regulatory signal(s) or by the cytotoxic components of apoptotic HUVECs (which might be due to the putative secondary necrosis of the cells undergoing anoikis), the important observation was that the activation of caspase-3 in target HUVECs was decreased in the presence of recombinant TGF- $\beta 1$. On the other hand, conditioned medium from anoikis HUVECs from where TGF- $\beta 1$ was neutralized by antibodies, markedly potentiated the activation of caspase-3 in the target cells (Figure 6d). These results suggest that activated TGF- $\beta$ is able to modulate HUVEC apoptosis leading to attenuation of cell death.

\section{Protective role of TGF- $\beta$ against HUVEC apoptosis}

To further elucidate the role of activated TGF- $\beta$ in apoptosis, we analysed first whether TGF- $\beta$ could modulate the level of cell death during staurosporine-induced apoptosis. We found that recombinant TGF- $\beta 1$ decreased the level of hypodiploid cells (cells containing fragmented DNA; Figure 7a). As staurosporine-induced apoptosis of HUVECs was associated with progressive detachment of dead cells, and because the detached cells were not taken into analysis to avoid possible secondary DNA fragmentation artefacts, we analysed the effect of TGF- $\beta$ on the level of cell detachment during staurosporine-induced apoptosis. We found that recombinant TGF- $\beta 1(1 \mathrm{ng} / \mathrm{ml})$ markedly attenuated the level of cell detachment during staurosporine-induced apoptosis (Figure $7 \mathrm{~b}$ ). At the same time, the protective effect of TGF- $\beta 1$, at least at the level of cell detachment, was almost totally abrogated by increased concentrations of TGF- $\beta 1$ (Figure 7b), suggesting dose-dependent biphasic effects for TGF- $\beta$ on apoptotic cell death.

Similarly to staurosporine-induced apoptosis, recombinant TGF- $\beta 1$ reduced, but anti-TGF- $\beta 1$ antibody potentiated the level of hypodiploidy during anoikis of HUVECs (Figure 7c), consistent with the hypothesis of a protective role for TGF- $\beta$ also against anoikis. Accordingly, recombinant TGF- $\beta 1$ attenuated the level of caspase-3 activity in anoikis HUVECs (Figure 7d), thus further suggesting protective effect of TGF- $\beta$ against anoikis.

As TGF- $\beta$ initiates Smad-dependent signalling via interaction with the type II TGF- $\beta$ receptors, we analysed whether TGF- $\beta$ receptor II would have effect on cell death during HUVEC anoikis. To explore this, HUVECs were incubated in serum-free medium without attachment in the presence of antibodies raised against TGF- $\beta$ receptor $\|^{26}$ for $5 \mathrm{~h}$. Unexpectedly, we found that anti-TGF- $\beta$ receptor II antibodies enhanced the phosphorylation of Smad2 protein in anoikis HUVECs (Figure 7e). The observed result thus resembled the effect of TGF- $\beta$ on the phosphorylation of Smad protein. However, the level of caspase-3 activity in anoikis HUVECs was markedly decreased in the presence of these, evidently agonizing antibodies against type II TGF- $\beta$ receptor (Figure 7e). The result thus suggests that TGF- $\beta$-dependent signalling via type II TGF- $\beta$ receptor could be directly involved in the attenuation of HUVEC apoptosis.

As ECM is considered to be a major storage compartment for the latent TGF- $\beta$ s, ${ }^{14}$ and because ECM can thus be one of the sources for activated TGF- $\beta$ during apoptosis (Figure 4), 
we investigated next the role of endogenous ECM in HUVEC apoptosis. For this aim, we induced anoikis of HUVECs by disruption of cell attachment with EDTA, followed by cell incubation in the presence of EDTA, either with or without endogenous ECM. Although anoikis in the absence of ECM is accompanied by the secretion and truncation of LL-TGF- $\beta$ from the cells (see Figure 5), we found that anoikis, which proceeded in the presence of endogenous HUVEC ECM (Figure 8a, (+ECM)), was accompanied by increased accumulation of truncated LL-TGF- $\beta$ into their supernatant fluids as compared to anoikis, which proceeded in the absence of ECM (Figure 8a, (-ECM)). Similarly, the major

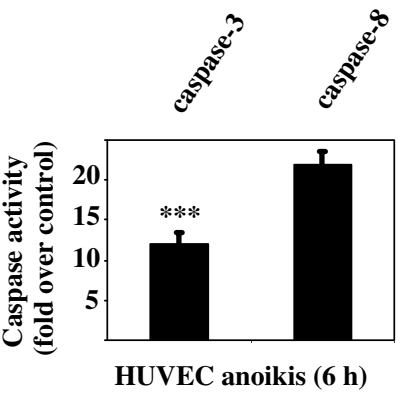

b

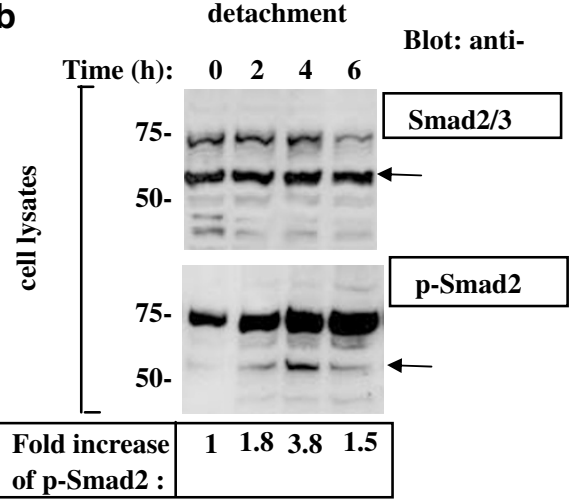

C detachment Blot: anti-

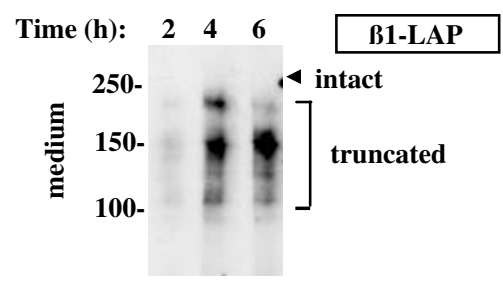

d

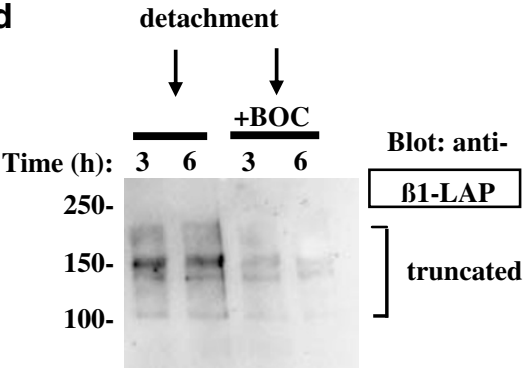

ECM protein, fibronectin, was increasingly released into the medium during anoikis, which proceeded in the presence of ECM, but did not accumulate during anoikis, which proceeded without endogenous ECM (Figure 8a, lower part). The results thus reveal the release of ECM proteins, such as fibronectin and LL-TGF- $\beta$, during HUVEC anoikis, which proceeded in the presence of endogenous ECM. In accordance with the hypothesis of the protective role of TGF- $\beta$ against apoptosis (Figure 7), we found that the activation of caspases was markedly attenuated in HUVECs undergoing anoikis in the presence of their ECM (Figure 8b). Accordingly, fluorescenceactivated cell sorting (FACS) analysis revealed that HUVEC anoikis in the presence of ECM was associated with reduced levels of hypodiploid cells (Figure 8c). The results further suggest a protective role for ECM proteins against HUVEC apoptosis.

\section{Discussion}

The secretion of mature TGF- $\beta$ as a part of the LL-TGF- $\beta$ complex and its subsequent storage to the ECM represent normal features of TGF- $\beta$ turnover. ${ }^{14}$ While a variety of mechanisms capable of converting latent TGF- $\beta$ to the active form in vitro have been described, the physiological conditions that promote the activation of latent TGF- $\beta$ need more elucidation.

Well-known examples for the role of TGF- $\beta$ are its activation during the resolving of lung inflammation. ${ }^{27,28}$ Increasing evidence suggests that apoptotic mechanisms may play important roles in the resolution of inflammation. ${ }^{29,30}$ One can therefore expect tight correlation between apoptosis and the activation of TGF- $\beta$.

By employing staurosporine-induced and attachmentimpaired models of HUVEC apoptosis, we find here that apoptosis of HUVECs is constantly associated with the activation of TGF- $\beta$. Activation of TGF- $\beta$ was also observed during HUVEC apoptosis, which was spontaneously induced in overgrown cultures (results not shown). The observation that the activation of TGF- $\beta$ accompanied also the apoptosis

Figure 5 Truncation of LL-TGF- $\beta$ complex and activation of TGF- $\beta$ during anoikis of HUVECs. Cells were resuspended in serum-free medium and incubated in culture plates covered with $1 \%$ low-melting point agarose for increasing periods of time. Following incubation, both the cells and conditioned medium were collected and analysed for caspase activity, phosphorylation of Smad (cell lysates), and accumulation of LL-TGF- $\beta$ complexes (medium). (a) Analysis of cell lysates for caspase activity. Values are means \pm S.D., $n=3$, ${ }^{* * *} P<0.001$. (b) Phosphorylation of Smad2 in the cells during anoikis. The polypeptides of the cell lysates were immunodetected by antibodies against $p$ Smad or Smad2/3. Total Smad2/3 proteins (upper panel) and phosphorylated Smad2 (lower panel) are indicated by arrows. (c) Release of truncated LL-TGF- $\beta$ complex during anoikis of HUVECs. The polypeptides accumulated into the medium were immunodetected by antibodies against $\beta 1$-LAP. Truncated LLTGF- $\beta$ is marked by brackets, and the migration of intact form by an arrowhead. (d) Release of truncated LL-TGF- $\beta$ into the medium of anoikis HUVECs is inhibited by pan-caspase inhibitor, BOC-D-fmk. The cells were incubated without detachment with the pan-caspase inhibitor, BOC-D-fmk (BOC, $75 \mu \mathrm{M})$. The released polypeptides were immunodetected by antibodies against $\beta 1$-LAP. Note that like in staurosporine-induced apoptosis (Figures 1-3), anoikis of HUVECs was accompanied by phosphorylation of Smad2 and release of truncated LL-TGF- $\beta$ into the medium, inhibitable by BOC-D-fmk 
a

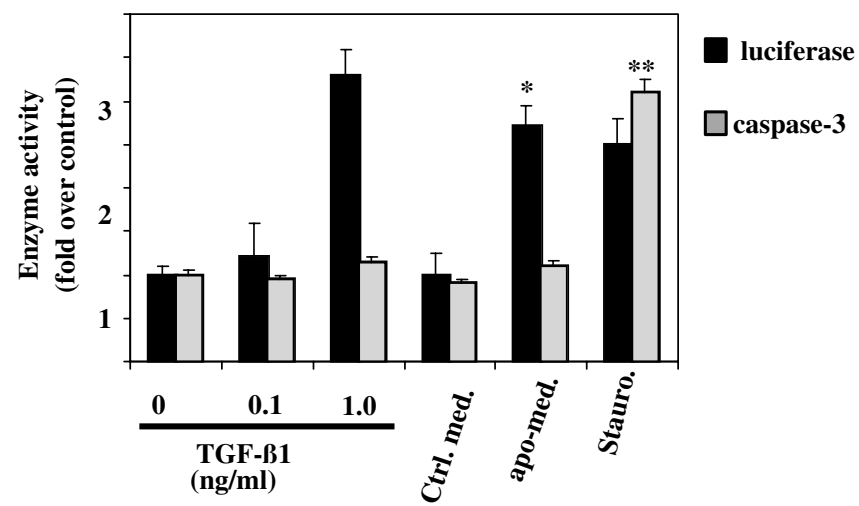

b

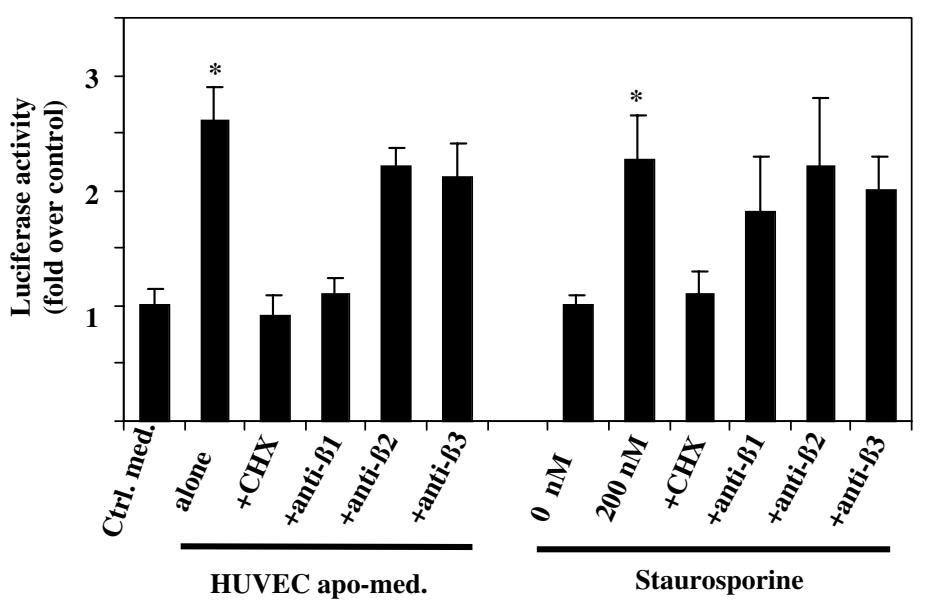

C

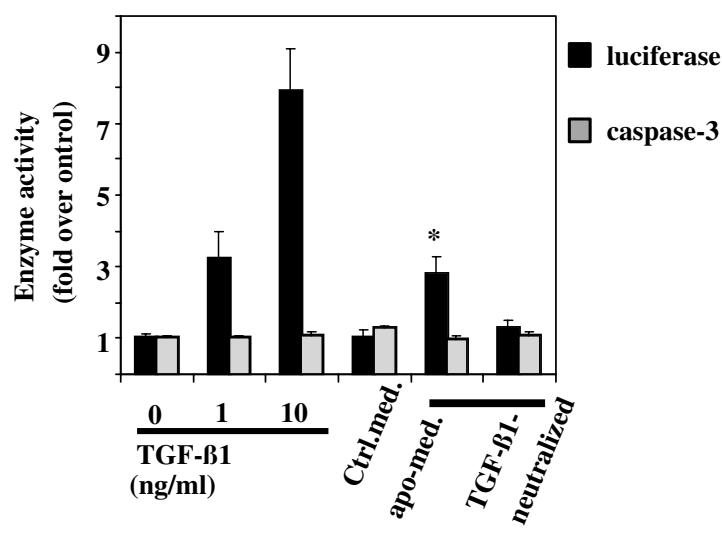

d

indicator: HUVECs

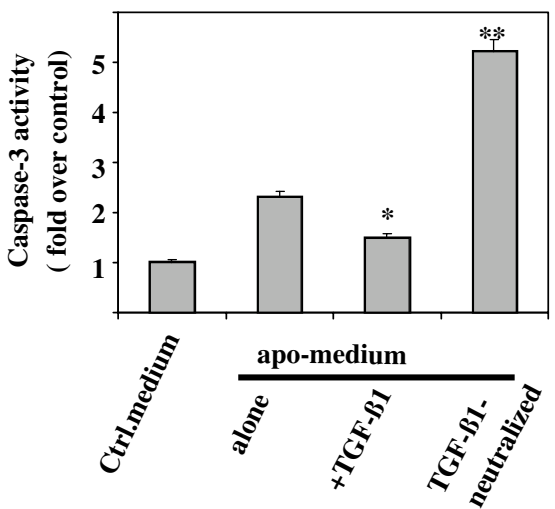

Figure 6 Conditioned medium from apoptotic HUVECs contains activated TGF- $\beta$. (a) Analysis of conditioned medium from staurosporine-treated cells. Mv1Lu cells transfected with luciferase reporter gene under TGF- $\beta$-sensitive PAl-1 promoter were incubated for $3 \mathrm{~h}$ with conditioned medium from apoptotic HUVECs ( $5 \mathrm{~h}$ incubation with $200 \mathrm{nM}$ staurosporine; 'apo-med.'), with conditioned medium from control HUVECs ( $5 \mathrm{~h}$ incubation without staurosporine; 'Ctrl. med.'), or with fresh serum-free medium containing $200 \mathrm{nM}$ staurosporine ('Stauro.'). As a positive control indicator, cells were incubated in serum-free medium containing increasing concentrations of TGF- $\beta 1$ for $3 \mathrm{~h}$. Following incubation, the Mv1Lu cells were analysed for caspase-3 and luciferase activities. Note that both conditioned medium from staurosporinetreated HUVECs and staurosporine alone induced luciferase activity in Mv1Lu cells, but only staurosporine alone induced caspase-3 activity in target Mv1Lu cells. (b) TGF- $\beta 1$ is predominantly activated during HUVEC apoptosis. Mv1Lu cells were incubated for $3 \mathrm{~h}$ with three types of media from apoptotic HUVECs as in (a) either alone or in the presence of $0.5 \mu \mathrm{g} / \mathrm{ml}$ cycloheximide, anti-TGF- $\beta 1$, anti-TGF- $\beta 2$, or anti-TGF- $\beta 3$ antibodies as indicated. Following incubation indicator Mv1Lu cells were analysed for luciferase activity. Cycloheximide and anti-TGF- $\beta 1$ antibody were the most effective ones in suppressing luciferase activity induced by conditioned medium from apoptotic HUVECs. (c) Analysis of conditioned medium from anoikis HUVECs. Mv1Lu cells were incubated for $3 \mathrm{~h}$ with conditioned medium from control HUVECs (serum-free medium from HUVECs at $5 \mathrm{~h}$; 'Ctrl. med.') or with conditioned medium from apoptotic (anoikis) HUVECs (serum-free medium from HUVECs after $5 \mathrm{~h}$ incubation without detachment; 'apo-medium') either alone or with pretested dilution of neutralizing anti-TGF- $\beta 1$ antibodies as indicated. As a positive control, Mv1Lu cells were incubated in serum-free medium containing increasing concentrations of TGF- $\beta 1$ for $3 \mathrm{~h}$. Following incubation, the cells were analysed for luciferase and caspase-3 activities. Note that conditioned medium from anoikis HUVECs induced luciferase activity in Mv1Lu cells inhibitable by anti-TGF- $\beta 1$ antibody. Induction of luciferase activity proceeded without concomitant caspase-3 activation. In all experiments, the values are given means \pm S.D., $n=3$. ${ }^{*} P<0.05$, ${ }^{* \star} P<0.01$ as compared to the 'control medium' group. (d) Conditioned medium from anoikis HUVECs induces apoptosis of target HUVECs inhibitable by activated TGF- $\beta$. Nonapoptotic target HUVECs were incubated for $4 \mathrm{~h}$ in serum-free control medium ('Ctrl. medium'), conditioned medium from anoikis HUVECs (serum-free medium harvested from HUVECs after $5 \mathrm{~h}$ incubation without detachment; 'apo-medium') either alone, in the presence of TGF- $\beta 1$ ( $1 \mathrm{ng} / \mathrm{ml})$, or with the same 'apo-medium' neutralized with both anti- $\beta 1$ LAP and anti-TGF- $\beta 1$ antibodies $(1 \mu \mathrm{g} / \mathrm{ml})$. Following incubation, target HUVECs were lysed and analysed for caspase- 3 activity. Values are means \pm S.D. $n=3$. ${ }^{\star} P<0.05$, ${ }^{* *} P<0.01$ as compared to the 'apo-medium' group. Note that while the conditioned medium from apoptotic cells, induced the activation of caspase-3 in the nonapoptotic target HUVECs, the level of caspase-3 activation was reduced to $\sim 70 \%(P<0.05)$ in the presence of TGF- $\beta 1$. The same medium was more effective in activating of caspase- 3 in target cells after neutralization of TGF- $\beta 1$ by antibodies

of Mv1Lu cells further implies the activation of TGF- $\beta$ as a common feature of the apoptotic response in different cell types. Current findings are complementary to a recent report on the involvement of endogenous TGF- $\beta 1$ in radiationinduced apoptosis of embryonic epithelial cells. ${ }^{31}$ Our results are also in accordance with observations on the induction of
TGF- $\beta$ synthesis during apoptosis, ${ }^{32}$ and secretion of both latent and active TGF- $\beta$ by apoptotic T cells. ${ }^{33}$ Recent reports demonstrating that either the loss ${ }^{34}$ or reduction of endogenous TGF- $\beta^{35}$ resulted in impaired neuronal cell death further suggest an important role for TGF- $\beta$ in the regulation of apoptotic cell death in vivo. 


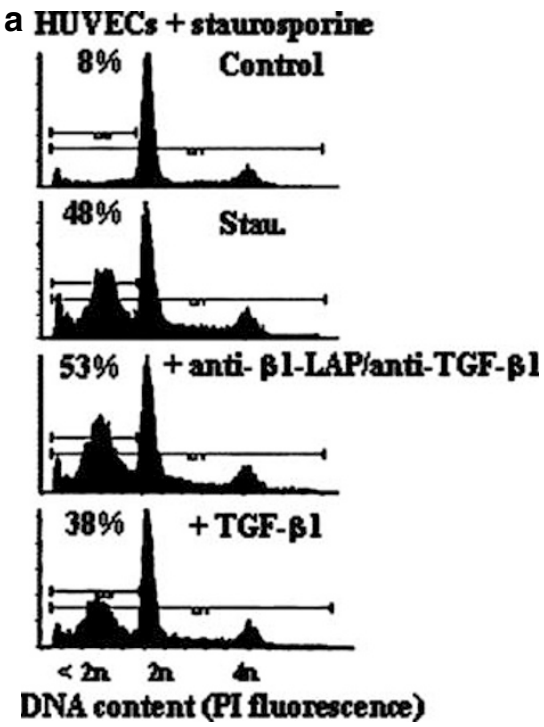

b

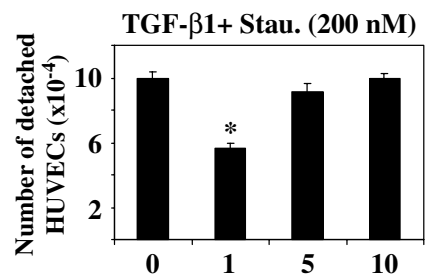

C HUVEC anoikis
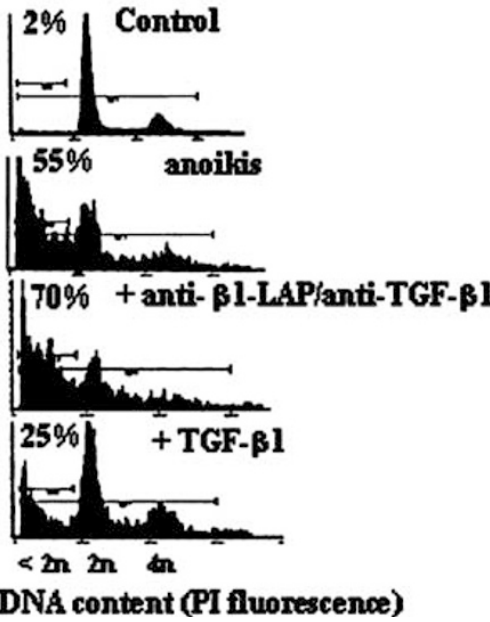

DNA content (PI fluorescenæe)

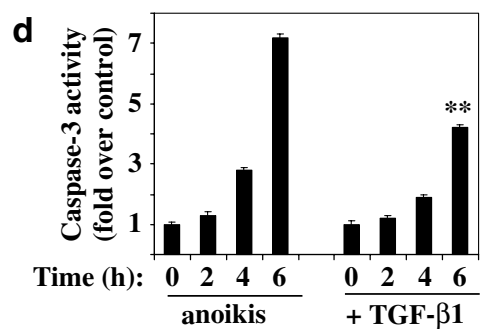

e
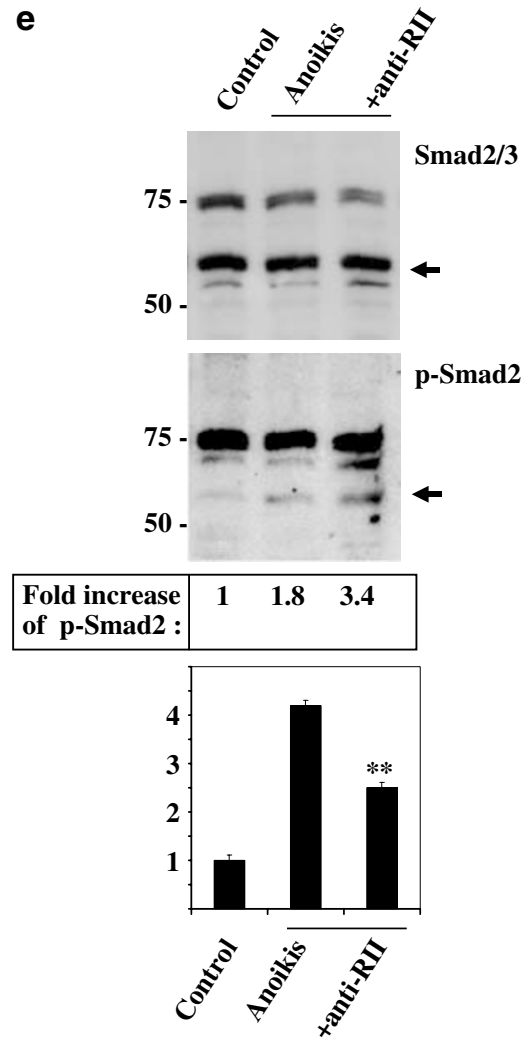

Figure 7 Activated TGF- $\beta$ modulates apoptosis of HUVECs. (a) TGF- $\beta$ reduces the level of cell death during staurosporine-induced apoptosis of HUVECs. Cells were treated with $200 \mathrm{nM}$ staurosporine either alone, in the presence of anti- $\beta 1$-LAP antibodies and anti-TGF- $\beta 1$ antibodies, or TGF- $\beta 1$ (1 ng/ml) for $7 \mathrm{~h}$ as indicated. Following treatment, the adherent cells were collected and analysed for DNA content by FACS. The distribution of cells according to the levels of ploidy (n) is shown. The proportion (\%) of cells in apoptotic (sub-diploid) peak is marked by $<2 n$. Data are representative of three independent experiments. (b) TGF- $\beta$ reduces the level of cell detachment. HUVECs were treated with $200 \mathrm{nM}$ staurosporine either alone or with increasing concentration of TGF- $\beta 1$ for $7 \mathrm{~h}$. After incubation, the number of detached cells was calculated by an electronic cell counter. Values are means \pm S.D. $n=3 .{ }^{\star} P<0.05$. (c) TGF- $\beta$ reduces the level of cell death during HUVEC anoikis. Cells were induced to undergo anoikis (incubation without attachment for $6 \mathrm{~h}$ ) either alone, in the presence of anti- $\beta 1$-LAP antibodies and anti-TGF- $\beta 1$ antibodies, or TGF- $\beta 1$ ( 1 ng/ $\mathrm{ml}$ ) as indicated. The distribution of cells according to the levels of ploidy (n) after $6 \mathrm{~h}$ of incubation is shown. Note that anti-TGF- $\beta 1$ antibodies increased, and TGF- $\beta 1$ reduced the proportion of apoptotic cells. (d) TGF- $\beta 1$ reduces caspase activity during anoikis of HUVECs. Cells were incubated without attachment to induce anoikis either alone or in the presence of TGF- $\beta 1(1 \mathrm{ng} / \mathrm{ml})$. The levels of caspase-3 activity were determined. Values are means \pm S.D. $n=3 .{ }^{* *} P<0.01$ as compared to the 'anoikis $6 \mathrm{~h}$ ' group. Note that TGF- $\beta 1$ reduced significantly the levels of caspase-3 activity during HUVEC anoikis. (e) Antibodies against type II TGF- $\beta 1$ receptor imitate the protective effect of TGF- $\beta$ during anoikis of HUVECs. Cells were incubated without attachment for $5 \mathrm{~h}$ to induce anoikis either alone or in the presence of $1 \mu \mathrm{g} / \mathrm{ml}$ antiTGF- $\beta 1$ receptor II antibodies (anti-RII). Following incubation, the cell lysates were analysed for Smad phosphorylation and caspase-3 activity. Total Smad2/3 proteins (upper panel) and phosphorylated Smad2 (middle panel) are indicated by arrows. The relative levels of Smad phosphorylation obtained by quantification of immunoreactive signals are given. The levels of caspase-3 activity are shown in the bottom. Values are means \pm S.D. $n=3 .{ }^{\star *} P<0.01$ as compared to the 'anoikis' group. Note that antibodies against type II TGF- $\beta 1$ receptor potentiated the level of Smad phosphorylation and reduced significantly the level of caspase-3 activity during anoikis of HUVECs

Numerous reports have provided evidence for the capacity of exogenous TGF- $\beta$ to induce apoptosis in target cells. ${ }^{36-39}$ Our results also revealed that apoptosis favouring conditions lead to the activation of endogenous TGF- $\beta$. One could therefore hypothesize that the activation of endogenous TGF$\beta$ is a component of the apoptotic response, which might potentiate the apoptotic cell death. Unexpectedly, activated TGF- $\beta$ attenuated HUVEC apoptosis. Although this observation is in line with several reports on the protective effect of TGF- $\beta$ against apoptosis of cells other than HUVECs, ${ }^{40,49-53}$ our observations are not in complete accordance with the findings on the apoptosis-inducing effect of recombinant TGF$\beta 1$ on bovine capillary endothelial cells. ${ }^{5}$ While attempting to reproduce those findings, we observed that HUVECs were markedly resistant to TGF- $\beta 1$-induced apoptosis (results not shown), consistent with observations by others. ${ }^{6}$ Rather, TGF- $\beta$ attenuated HUVEC apoptosis, although its protective effect, at least during staurosporine-induced apoptosis, was almost totally abrogated by higher concentrations of TGF- $\beta 1$ (Figure 7). The results suggest that physiological effects of endogenously activated TGF- $\beta$ may differ from the effects of exogenous TGF- $\beta$. At the same time, while recombinant TGF$\beta 1$ per se was not effective in inducing cell death of HUVECs, some initial activation of TGF- $\beta$ (i.e. phosphorylation of Smad2) was observed almost immediately after the initiation of HUVEC apoptosis by staurosporine (Figure 1), suggesting a highly sensitive role for endogenous TGF- $\beta$ to apoptotic challenging.

Both the accumulation of truncated LL-TGF- $\beta$ and the phosphorylation of Smad could be inhibited by the 
a

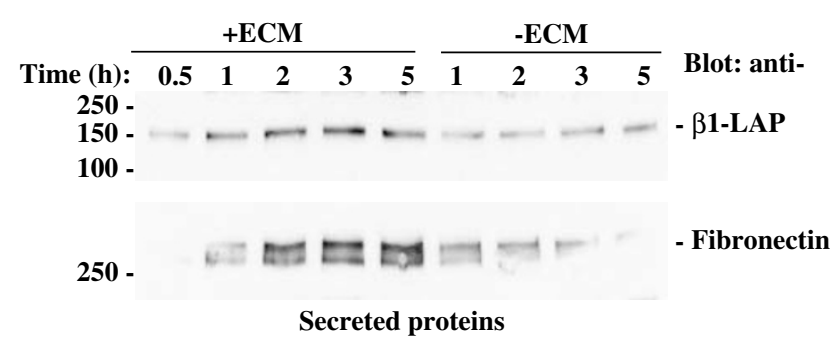

b

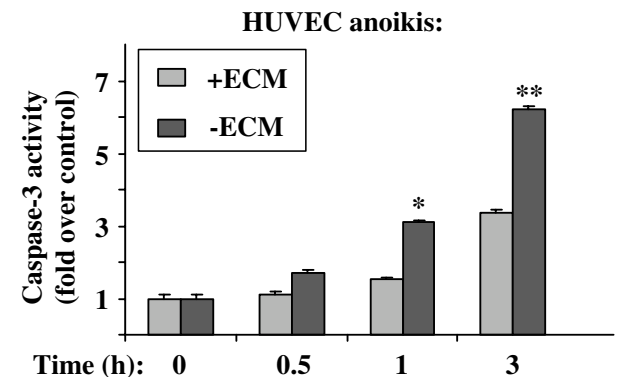

C HUVEC anoikis:
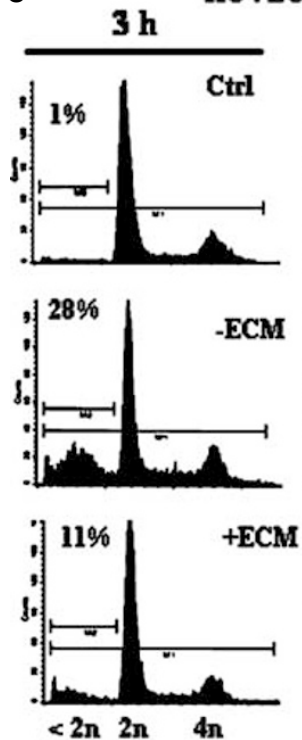

$5 \mathrm{~h}$
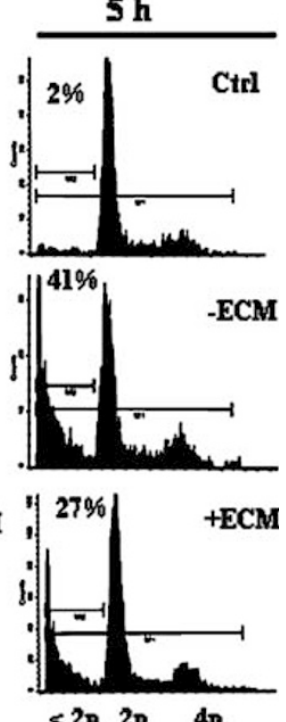

Figure 8 Protective effect of endogenous ECM against anoikis of HUVECs. Subconfluent HUVECs were treated with EDTA (1 mM) for 30 min to induce cell detachment. After detachment, the cells were incubated with EDTA for increasing periods of time, either in the 'conditioned' cell culture plate containing their own endogenous ECM ( + ECM), or in culture plates covered with agarose (-ECM). (a) Analysis of secreted polypeptides. The polypeptides accumulated into the medium were immunodetected by antibodies against TGF $\beta 1$-LAP (upper part) or fibronectin (lower part). Note that anoikis in the presence of endogenous ECM was associated with more profound release of both truncated LL-TGF- $\beta$ and fibronectin into the conditioned medium. (b) Endogenous ECM attenuates caspase-3 activation during anoikis. Cells undergoing anoikis were analysed for caspase- 3 activity. Values are means \pm S.D., $n=3,{ }^{\star} P<0.05,{ }^{\star *} P<0.01$ as compared to the ' $+E C M$ ' group. (c) Endogenous ECM reduces the level of DNA fragmentation during HUVEC anoikis. Cells were induced to undergo anoikis either with or without endogenous ECM as indicated. After 3 and $5 \mathrm{~h}$, the cells were collected and analysed for DNA content by FACS. The distribution of cells according to the levels of ploidy (n) is shown. The percentage of cells in apoptotic (sub-diploid) peak is marked by $<2 n$. Note that the level of hypodiploid cells was reduced in HUVECs undergoing anoikis in the presence of endogenous ECM

pan-caspase inhibitor, BOC-D-fmk, providing further evidence for the relevance of TGF- $\beta$ activation to apoptosis. Interestingly, while suppressing the release from cell layers of truncated LL-TGF- $\beta$, BOC-D-fmk did not prevent but initiated the decline of Smad phosphorylation, which was progressively increased in the absence of BOC-D-fmk (Figure 3). These data suggest that the activation of TGF- $\beta$ takes place at the early stages of apoptosis regardless of caspase activation status, implying the activation of TGF- $\beta$ taking place prior to the activation of caspases. This is further supported by the observation that at least in the presence of endogenous ECM the release of truncated LL-TGF- $\beta$ into the conditioned medium precedes caspase activation during anoikis of HUVECs (Figure 8). Together with the observation on the protective effect of activated TGF- $\beta$ against HUVEC apoptosis, our data imply that activated TGF- $\beta$ may serve as an early checkpoint factor to protect the cells at the beginning of apoptosis. This view is consistent with our observation that activated TGF- $\beta$ does not prevent, but just attenuates the apoptotic death of HUVECs (Figures 7 and 8).

Similar protective effects against at least anoikis of intestinal epithelial cells have recently been reported for TGF $-\alpha,{ }^{41}$ suggesting a common role for different TGFs in the modulation of apoptotic cell death. Interestingly, exogenous TGF- $\alpha$ exerted its protective effect by partial reversion of detachment-induced inhibition of C-Src kinase activity and Bcl$\mathrm{X}(\mathrm{L})$ expression. ${ }^{41}$ Whether the endogenously activated TGF$\beta$ attenuates HUVEC apoptosis via similar mechanisms needs further elucidation. Our observation that stimulation of Smad signalling by agonizing antibodies against type II TGF- $\beta$ receptor imitates the protective effect of TGF- $\beta$ against HUVEC anoikis (Figure 7) implies a direct role for Smad signalling in attenuation of HUVEC apoptosis.

Our data reveal that the activation of TGF- $\beta$ during apoptosis of HUVECs is constantly associated with the release into the conditioned medium of two major forms of truncated LL-TGF- $\beta$ of $\sim 200$ and $140 \mathrm{kDa}$. Neither of these truncated forms could be detected in the cell lysates despite the abundant levels of $\sim 50$ - and $100 \mathrm{kDa}$ LAP proteins (Figure 4). Together with the observation on the release of ECM-bound LTBP-1 during HUVEC apoptosis (Figure 4), our data imply an important role for the extracellular proteolysis of LTBPs in the activation of TGF- $\beta$ during apoptosis. This is in line with our recent observation that the disruption of the expression of one of the LTBPs, that is, LTBP-4, reduced significantly TGF- $\beta$ activation in lung fibroblasts. ${ }^{44}$

The protease-dependent activation of TGF- $\beta$ is likely to involve the cleavage of the ECM-bound LL-TGF- $\beta$ complex within the protease-sensitive hinge region to release $\sim 200 \mathrm{kDa}$ truncated LL-TGF- $\beta^{24}$ (see also Figure 2). Thus, while the truncation of LL-TGF- $\beta$ into $\sim 200 \mathrm{kDa}$ fragments during apoptosis was expected, the mechanism of generation of $\sim 140 \mathrm{kDa}$ LL-TGF- $\beta$ needs further elucidation. Proteolytic processing of LTBPs at several cleavage sites, as well as the cleavage of LL-TGF- $\beta$ within LAP region would provide a reason for generation of truncated $\sim 140 \mathrm{kDa}$ LL-TGF- $\beta$ during HUVEC apoptosis. Interestingly, the serine protease inhibitor, AEBSF, while effectively suppressing the release of 
truncated LTBP-1 into the medium, possessed a marginal effect on the truncation of LL-TGF- $\beta$ (Figure 2 ). These results implicate that also the other LTBPs (especially LTBP-3 and -4) may get truncated during apoptosis. As antibodies available against TGF- $\beta 1$-LAP recognize its large latent complexes between LTBP-1, -3 , and $-4,{ }^{42}$ we cannot distinguish at present whether all of these LTBPs are equally processed during apoptosis of HUVECs.

Current data suggest that proteolytic release of ECM-bound LTBPs may represent a major mechanism for the activation of TGF- $\beta$ under physiological conditions. ${ }^{24,46}$ Our data are further suggestive of two sources for activation of TGF- $\beta$ during apoptosis of HUVECs: the secretion of intracellular TGF- $\beta$ from apoptotic cells and the proteolytic release of stored LL-TGF- $\beta$ from the ECM. Both of these sources appear to be utilized during apoptosis of HUVECs, as in the anoikis model of apoptosis the activation of TGF- $\beta$ can be observed despite the lack of endogenous ECM (Figure 5). In addition, apoptotic HUVECs produced protease-like activity capable of releasing truncated $L T B P$ s from isolated ECM in a manner resembling that of plasmin (Figure 4), mast cell chymase or leukocyte elastase. ${ }^{24}$ Our model of HUVEC anoikis, induced either with or without endogenous ECM (Figure 8), further illustrates the contribution of both ECM- and cell-derived LL-TGF- $\beta$ in the activation of TGF- $\beta$ during apoptosis.

Our results indicate that apoptosis of HUVECs is constantly associated with the activation of TGF- $\beta$, a cytokine, which normally is localized in the pericellular space. The secretion of TGF- $\beta$ from apoptotic cells and the release of the latent TGF- $\beta$ complexes from the ECM provide two sources for the generation of active TGF- $\beta$ during HUVEC apoptosis. While extensive knowledge is currently available on the mechanisms of apoptotic execution within the cells, ${ }^{1-6,8,7}$ it becomes necessary to recognize apoptosis as a tissue phenomenon. This suggests that extracellular regulatory signals may operate between the apoptosizing cells and their nonapoptotic neighbours. The first example of such cooperation has been recently reported in Drosophila. ${ }^{43}$ Our findings on the involvement of ECM as an important source for activatable TGF- $\beta$ during HUVEC apoptosis implicates a critical role for ECM-bound TGF- $\beta$ as a putative extracellular modulator of apoptosis.

\section{Materials and Methods}

\section{Cell cultures}

HUVECs were purchased from Promocell (Heidelberg, Germany), and were cultured in Endothelial Cell Growth Medium (Promocell) in humidified $5 \% \mathrm{CO}_{2}$ atmosphere at $37^{\circ} \mathrm{C}$. The cells used for the experiments were from passages 3-9. Human embryonic lung fibroblasts (HEL-299; CCL137, American Type Culture Collection, Rockville, MD, USA) were cultured in minimal essential medium (MEM) supplemented with $10 \%$ heatinactivated fetal calf serum (Gibco, Invitrogen Corporation), $100 \mathrm{U} / \mathrm{ml}$ penicillin, and $50 \mu \mathrm{g} / \mathrm{ml}$ streptomycin. Mink lung Mv1Lu cells, both wild type and transfected with luciferase under promoter of plasminogenactivator inhibitor-1 gene, were gifts from Dr. DB Rifkin (NY University School of Medicine, New York, NY, USA). Mv1Lu cells were maintained in Dulbecco's modified Eagle's medium supplemented with $10 \%$ heatinactivated fetal calf serum, $100 \mathrm{U} / \mathrm{ml}$ penicillin, $100 \mu \mathrm{g} / \mathrm{ml}$ streptomycin,
L-glutamine. Medium for maintaining transfected Mv1Lu contained 200 $\mu \mathrm{g} / \mathrm{ml}$ geneticin (G418).

\section{Induction of apoptosis}

Exponentially growing HUVECs were washed three times for $5 \mathrm{~min}$, each with prewarmed serum-free medium. Apoptosis was then induced by treatment of the cells with staurosporine (100-200 nM) under serum-free conditions. To induce attachment-impaired apoptosis (anoikis), the cells were trypsinized and washed twice with serum-free medium, followed by incubation in culture plates covered with $1 \%$ low-melting point agarose in serum-free medium to prevent cell attachment. To induce anoikis in the presence or in the absence of endogenous ECM, the subconfluent cultures were treated with PBS supplemented with $1 \mathrm{mM}$ EDTA. After detachment ( $\sim 20$ min of incubation), the cells were incubated in the presence of $1 \mathrm{mM}$ EDTA, either in 'conditioned' cell culture plate (ECMcontaining) or in fresh culture plate covered with agarose.

\section{Analysis of caspase activity}

Samples normalized for the cell number were lysed with ice-cold hypotonic buffer (10 mM PIPES, $10 \mathrm{mM} \mathrm{KCl,} 1 \mathrm{mM}$ dithiothreitol, $2 \mathrm{mM} \mathrm{MgCl}$, $0.1 \mathrm{mM}$. EDTA, $0.1 \mathrm{mM}$ EGTA, $0.1 \mathrm{mM}$ phenylmethanesulphonyl fluoride, $\mathrm{pH}$ 7.5). The activity of caspase- 3 and -8 in cytosolic extracts was assayed using $20 \mu \mathrm{M}$ fluorogenic substrates Ac-DEVD-AMC (Pharmingen) and Z-IETD-AFC (Calbiochem), respectively, according to the manufacturer's protocol. Caspase activity was measured as emission events of the cleaved AMC or AFC fluorochrome (c.p.s./mg protein) and normalized to the activity of the control cell lysate.

\section{Analysis of luciferase activity}

Confluent or subconfluent Mv1Lu cells, transfected with luciferase reporter gene under PAl-1 promoter, were trypsinized, washed with culture medium, and plated in 96-well cell culture dishes at the density of $\sim 10^{5}$ cells per well. After $6-12 \mathrm{~h}$, the cells were treated either with recombinant TGF- $\beta 1$ or with conditioned medium from apoptotic cells for $3-4 \mathrm{~h}$ as indicated. After treatment, the luciferase activity of the cell lysates was measured using luciferase assay system (Promega, Madison, USA) according to the manufacturer's protocol, and normalized to the activity of the control cell lysate.

\section{Flow cytometric analysis}

Samples containing both adherent and floating cells were fixed in $\mathrm{EtOH}$ and treated with RNase A (50 $\mu \mathrm{g} / \mathrm{ml}$, Sigma Chemical Co, St. Louis, MO, USA) followed by staining with propidium iodide $(100 \mu \mathrm{g} / \mathrm{ml})$. Acquisition of events was carried out with FACSCalibur flow cytometer and CellQuest program (Becton Dickinson, Franklin Lakes, NJ, USA), and DNA analysis was performed by ModFit LT versus 3.0 (Verity Ltd., Topsham, ME, USA).

\section{Antibodies}

Polyclonal antibody Ab-39 has been raised against purified human platelet LTBP-1 (free form, devoid of LAP and TGF- $\beta$ ). ${ }^{45}$ This antibody is functional in immunoblotting and immunoprecipitation of LTBP-1 under nonreducing conditions, but does not react with reduced LTBP-1. Anti-phospho-Smad2 antiserum has been generated against the phosphorylated $\mathrm{C}$-tail of Smad2. ${ }^{47}$ Anti-phospho-Smad2 recognizes two phosphoserine residues of the $\mathrm{C}$-terminal domain of Smad2 but does not react with phosphorylated 
Smad1. ${ }^{47}$ Goat affinity-purified antibodies (IgG fraction), AF 241-NA, raised against the type II TGF- $\beta$ receptor, ${ }^{26}$ polyclonal anti-LAP (TGF- $\beta 1$ ), anti-TGF- $\beta 2$, anti-TGF- $\beta 3$, and anti-human TGF- $\beta 1$ antibodies were from R\&D Systems (Minneapolis, MN, USA). Monoclonal anti-fibronectin and anti-Smad2/3 antibodies were from Sigma (St. Louis, MO, USA) and from Transduction Laboratories (Lexington, KY, USA). Anti-Smad2/3 antibody reacts with both phosphorylated and nonphosphorylated Smad2, as well as with Smad3. Streptavidin antibodies, biotin- and horseradish peroxidase-conjugated goat anti-rabbit, goat anti-mouse, and rabbit antigoat antibodies were from DAKO (Glostrup, Denmark).

\section{SDS-PAGE and immunoblotting}

Cell conditioned medium was concentrated on a Microcon 30 concentrator (Amicon). The polypeptides of the medium were separated by $4-15 \%$ gradient SDS-PAGE under nonreducing conditions. The proteins were then electrophoretically transferred onto nitrocellulose filters under semidry conditions. To prevent nonspecific reactivity, the filters were incubated in $5 \%$ nonfat milk powder in Tris-HCl-buffered saline, $\mathrm{pH} 7.5$, containing $0.05 \%$ Tween-20. After incubation with primary antibodies, the immunoreactive bands were detected by horseradish peroxidaseconjugated secondary antibodies followed by enhanced chemiluminescence (ECL, Pierce). LL-TGF- $\beta$ complexes in the conditioned medium were immunodetected by anti- $\beta 1$-LAP or anti-LTBP-1 antibodies under nonreducing conditions. For the detection of the Smad proteins, the cells were washed with ice-cold PBS and lysed with Laemmli sample buffer under reducing conditions. Immunoblotting with both anti-phospho-Smad antiserum (IgG fraction) and monoclonal anti-Smad2 antibody was performed as described above, with the exception that biotinylated peroxidase-conjugated streptavidin was used as the last conjugate (Amersham Pharmacia Biotech, Piscataway, NJ, USA).

\section{Isolation of the ECM}

ECMs were prepared essentially as described. ${ }^{48}$ Briefly, HUVECs or human fetal lung fibroblasts were washed with PBS and treated three

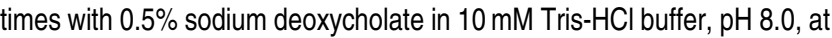
$0^{\circ} \mathrm{C}$ for $10 \mathrm{~min}$. Subsequently, the matrices were washed three times with PBS and used for the digestion assays.

\section{Quantification of immunoreactive signals}

For quantification of immunoreactive signals, the levels of intensity of the immunoreactive bands were measured using Adobe Photoshop software and normalized to the level of the control.

\section{Statistics}

All values have been expressed as mean \pm S.D. of 3-5 experiments. Data were analyzed using the unpaired $t$-test. A value $P<0.05$ was denoted statistically significant.

\section{Acknowledgements}

We thank Dr. Daniel B Rifkin for providing the Mv1Lu cells. We further thank Drs Jussi Taipale, Katri Koli, Sara Wickström and Marko Hyytiäinen for critical comments and Sami Starast and Anne Remes for fine technical assistance. This work was supported by the Academy of Finland, Sigrid Juselius Foundation, Novo Nordisk Foundation, TEKES, Finnish Cancer
Foundation, Helsinki University Hospital Fund, Biocentrum Helsinki and the University of Helsinki.

\section{References}

1. Webb SJ, Harrison DJ and Wyllie AH (1997) Apoptosis: an overview of the process and its relevance in disease. Adv. Pharmacol. 41: 1-34

2. Earnshaw WC, Martins LM and Kaufmann SH (1999) Mammalian caspases: structure, activation, substrates, and functions during apoptosis. Annu. Rev. Biochem. 68: 383-424

3. Nagata S (2000) Apoptotic DNA fragmentation. Exp. Cell Res. 256: 12-18

4. Pollman MJ, Naumovski L and Gibbons GH (1999) Vascular cell apoptosis: cell type-specific modulation by transforming growth factor- $\beta 1$ in endothelial cells versus smooth muscle cells. Circulation 99: 2019-2026

5. Hyman KM, Seghezzi G, Pintucci G, Stellari G, Kim JH, Grossi EA, Galloway $A C$ and Mignatti $P$ (2002) Transforming growth factor- $\beta 1$ induces apoptosis in vascular endothelial cells by activation of mitogen-activated protein kinase. Surgery 132: 173-179

6. Emmanuel C, Foo E, Medbury HJ, Matthews J, Comis A and Zoellner H (2002) Synergistic induction of apoptosis in human endothelial cells by tumour necrosis factor- $\alpha$ and transforming growth factor- $\beta$. Cytokine 18: 237-241

7. Ackermann EJ, Taylor JK, Narayana R and Bennett CF (1999) The role of antiapoptotic Bcl-2 family members in endothelial apoptosis elucidated with antisense oligonucleotides. J. Biol. Chem. 274: 11245-11252

8. Stoneman VE and Bennett MR (2004) Role of apoptosis in atherosclerosis and its therapeutic implications. Clin. Sci. 107: 343-354

9. Chavakis $E$ and Dimmeler $S$ (2002) Regulation of endothelial cell survival and apoptosis during angiogenesis. Arterioscler. Thromb. Vasc. Biol. 22: 887-893

10. Annes JP, Munger JS and Rifkin DB (2003) Making sense of latent TGF- $\beta$ activation. J. Cell Sci. 116: 217-224

11. Taipale J, Saharinen J and Keski-Oja J (1998) Extracellular matrix-associated transforming growth factor- $\beta$ : role in cancer cell growth and invasion. Adv. Cancer Res. 75: 87-134

12. Kanzaki T., Olofsson A, Moren A, Wernstedt C, Hellman U, Miyazono K, Claesson-Welsh $L$ and Heldin CH (1990) TGF- $\beta 1$ binding protein: a component of the large latent complex of TGF- $\beta 1$ with multiple repeat sequences. Cell 61 : 1051-1061

13. Saharinen J, Hyytiäinen M, Taipale J and Keski-Oja J (1999) Latent transforming growth factor- $\beta$ binding proteins (LTBPs) - structural extracellular matrix proteins for targeting TGF- $\beta$ action. Cytokine Growth Factor Rev. 10: $99-117$

14. Taipale J, Miyazono K, Heldin CH and Keski-Oja J (1994) Latent transforming growth factor- $\beta 1$ associates to fibroblast extracellular matrix via latent TGF- $\beta$ binding protein. J. Cell Biol. 124: 171-181

15. Koli K, Saharinen J, Hyytiäinen M, Penttinen C and Keski-Oja J (2001) Latency, activation, and binding proteins of TGF- $\beta$. Microsc. Res. Tech. 52: 354-362

16. Schultz-Cherry S and Murphy-Ullrich JE (1993) Thrombospondin causes activation of latent transforming growth factor $-\beta$ secreted by endothelial cells by a novel mechanism. J. Cell Biol. 122: 923-932

17. Munger JS, Huang X, Kawakatsu H, Griffiths MJ, Dalton SL, Wu J, Pittet JF, Kaminski N, Garat C, Matthay MA, Rifkin DB and Sheppard D (1999) The integrin $\alpha_{v} \beta_{6}$ binds and activates latent TGF- $\beta 1$ : a mechanism for regulating pulmonary inflammation and fibrosis. Cell 96: 319-328

18. Annes JP, Chen Y, Munger JS and Rifkin DB (2004) Integrin $\alpha_{v} \beta_{6}$-mediated activation of latent TGF- $\beta$ requires the latent TGF- $\beta$ binding protein- 1 . J. Cell Biol. 165: 723-734

19. Lyons RM, Keski-Oja J and Moses HL (1988) Proteolytic activation of latent transforming growth factor $-\beta$ from fibroblast-conditioned medium. J. Cell Biol. 106: $1659-1665$

20. Sato $Y$ and Rifkin DB (1989) Inhibition of endothelial cell movement by pericytes and smooth muscle cells: activation of a latent transforming growth factor- $\beta 1$-like molecule by plasmin during co-culture. J. Cell Biol. 109: 309-315

21. Karsdal MA, Larsen L, Engsig MT, Lou H, Ferreras M, Lochter A, Delaisse JM and Foged NT (2002) Matrix metalloproteinase-dependent activation of latent transforming growth factor- $\beta$ controls the conversion of osteoblasts into osteocytes by blocking osteoblast apoptosis. J. Biol. Chem. 277: 44061-44067 
22. Yu $Q$ and Stamenkovic I (2000) Cell surface-localized matrix metalloproteinase- 9 proteolytically activates TGF- $\beta$ and promotes tumor invasion and angiogenesis. Genes Dev. 14: 163-176

23. Guo M, Mathieu PA, Linebaugh B, Sloane BF and Reiners JJJr (2002) Phorbol ester activation of a proteolytic cascade capable of activating latent transforming growth factor- $\beta$ : a process initiated by the exocytosis of cathepsin B. J. Biol. Chem. 277: 14829-14837

24. Taipale J, Lohi J, Saarinen J, Kovanen PT and Keski-Oja J (1995) Human mast cell chymase and leukocyte elastase release latent transforming growth factor$\beta 1$ from the extracellular matrix of cultured human epithelial and endothelial cells. J. Biol. Chem. 270: 4689-4696

25. Abe M, Harpel JG, Metz CN, Nunes I, Loskutoff DJ and Rifkin DB (1994) An assay for transforming growth factor- $\beta$ using cells transfected with a plasminogen activator inhibitor-1 promoter-luciferase construct. Anal. Biochem. 216: 276-284

26. Guimond A, Sulea T, Pen A, Ear P and O'Connor-McCourt MD (2002) Sitedirected mutagenesis of the type II TGF- $\beta$ receptor indicates a ligand-binding site distinct from that of the type II activin receptor. FEBS Lett. 515: 13-19

27. Blobe GC, Schiemann WP and Lodish HF (2000) Role of transforming growth factor- $\beta$ in human disease. New Engl. J. Med. 342: 1350-1358

28. Teder P, Vandivier RW, Jiang D, Liang J, Cohn L, Pure E, Henson PM and Noble PW (2002) Resolution of lung inflammation by CD44. Science 296: $155-158$

29. Huynh ML, Fadok VA and Henson PM (2002) Phosphatidylserine-dependent ingestion of apoptotic cells promotes TGF- $\beta 1$ secretion and the resolution of inflammation. J. Clin. Invest. 109: 41-50

30. Lawrence T, Gilroy DW, Colville-Nash PR and Willoughby DA (2001) Possible new role for NF- $\kappa B$ in the resolution of inflammation. Nat. Med. 7: 1291-1297

31. Ewan KB, Henshall-Powell RL, Ravani SA, Pajares MJ, Arteaga C, Warters R, Akhurst RJ and Barcellos-Hoff MH (2002) Transforming growth factor- $\beta 1$ mediates cellular response to DNA damage in situ. Cancer Res. 62: 5627-5631

32. Hodge S, Hodge G, Flower R, Reynolds PN, Scicchitano R and Holmes M (2002) Up-regulation of production of TGF- $\beta$ and IL-4 and down-regulation of IL-6 by apoptotic human bronchial epithelial cells. Immunol. Cell Biol. 80: 537-543

33. Chen $W$, Jin $W$, Tian $H$, Sicurello $P$, Frank $M$, Orenstein JM and Wahl SM (2001) Requirement for transforming growth factor- $\beta 1$ in controlling $T$ cell apoptosis. J. Exp. Med. 194: 439-453

34. Brionne T, Tesseur Cl, Masliah E and Wyss-Coray T (2003) Loss of TGF- $\beta 1$ leads to increased neuronal cell death and microgliosis in mouse brain. Neuron 40: 1133-1145

35. Krieglstein K, Richter S, Farkas L, Schuster N, Dunker N, Oppenheim RW and Unsicker K (2000) Reduction of endogenous transforming growth factors- $\beta$ prevents ontogenetic neuron death. Nat. Neurosci. 3: 1085-1090

36. Dai C, Yang J and Liu Y (2003) Transforming growth factor- $\beta 1$ potentiates renal tubular epithelial cell death by a mechanism independent of smad signalling. J. Biol. Chem. 278: 12537-12545

37. Barna G, Sebestyen A, Chinopoulos CC, Nagy K, Mihalik R, Paku S and Kopper $L$ (2002) TGF- $\beta 1$ kills lymphoma cells using mitochondrial apoptotic pathway with the help of caspase-8. Anticancer Res. 22: 3867-3872

38. Ramachandra M, Atencio I, Rahman A, Vaillancourt M, Zou A, Avanzini J, Wills $\mathrm{K}$, Bookstein R and Shabram P (2002) Restoration of transforming growth factor $-\beta$ signalling by functional expression of smad4 induces anoikis. Cancer Res. 62: 6045-6051
39. Valderrama-Carvajal H, Cocolakis E, Lacerte A, Lee EH, Krystal G, Ali S and Lebrun JJ (2002) Activin/TGF- $\beta$ induce apoptosis through Smaddependent expression of the lipid phosphatase SHIP. Nat. Cell Biol. 4: 963-969

40. Zhu Y, Yang GY, Ahlemeyer B, Pang L, Che XM, Culmsee C, Klumpp S and Krieglstein J (2002) Transforming growth factor- $\beta 1$ increases bad phosphorylation and protects neurons against damage. J. Neurosci. 22: 3898-3909

41. Rosen K, Coll ML, Li A and Filmus J (2001) Transforming growth factor- $\alpha$ prevents detachment-induced inhibition of c-Src kinase activity, Bcl-XL downregulation, and apoptosis of intestinal epithelial cells. J. Biol. Chem. 276: 37273-37279

42. Saharinen J and Keski-Oja J (2000) Specific sequence motif of 8-Cys repeats of TGF- $\beta$ binding proteins, LTBPs, creates a hydrophobic interaction surface for binding of small latent TGF- $\beta$. Mol. Biol. Cell 11: 2691-2704

43. Ryoo HD, Gorenc T and Steller H (2004) Apoptotic cells can induce compensatory cell proliferation through the JNK and the Wingless signalling pathways. Dev. Cell. 7: 491-501

44. Koli K, Wempe F, Sterner-Kock A, Kantola A, Komor M, Hofmann WK, von Melchner $\mathrm{H}$ and Keski-Oja J (2004) Disruption of LTBP-4 function reduces TGF- $\beta$ activation and enhances BMP-4 signaling in the lung. J. Cell Biol. 167: 123-133

45. Miyazono K, Olofsson A, Colosetti P and Heldin CH (1991) A role of the latent TGF- $\beta 1$-binding protein in the assembly and secretion of TGF- $\beta 1$. EMBO J. 10 : 1091-1101

46. Dallas SL, Rosser JL, Mundy GR and Bonewald LF (2002) Proteolysis of latent transforming growth factor- $\beta$ (TGF- $\beta$ )-binding protein- 1 by osteoclasts. A cellular mechanism for release of TGF- $\beta$ from bone matrix. J. Biol. Chem. 277: 21352-21360

47. Persson U, Izumi H, Souchelnytskyi S, Itoh S, Grimsby S, Engstrom U, Heldin $\mathrm{CH}$, Funa K and ten Dijke P (1998) The L45 loop in type I receptors for TGF- $\beta$ family members is a critical determinant in specifying Smad isoform activation. FEBS Lett. 434: 83-87

48. Hedman K, Kurkinen M., Alitalo K, Vaheri A, Johansson S and Höök M (1979) Isolation of the pericellular matrix of human fibroblast cultures. J. Cell Biol. 81: 83-91

49. Brunetti M, Martelli N, Manarini S, Mascetra N, Musiani P, Cerletti C, Aiello FB and Evangelista V (2000) Polymorphonuclear leukocyte apoptosis is inhibited by platelet-released mediators, role of TGF- $\beta 1$. Thromb. Haemost. 84: $478-483$

50. Schlapbach R, Spanaus KS, Malipiero U, Lens S, Tasinato A, Tschopp J and Fontana A (2000) TGF- $\beta$ induces the expression of the FLICE-inhibitory protein and inhibits Fas-mediated apoptosis of microglia. Eur. J. Immunol. 30: 3680-3688

51. Saile B, Matthes NE, Armouche H, Neubauer K and Ramadori G (2001) The bcl, NFkappaB and p53/p21WAF1 systems are involved in spontaneous apoptosis and in the anti-apoptotic effect of TGF- $\beta$ or TNF- $\alpha$ on activated hepatic stellate cells. Eur. J. Cell Biol. 80: 554-561

52. Shin I, Bakin AV, Rodeck U, Brunet A and Arteaga CL (2001) Transforming growth factor $\beta$ enhances epithelial cell survival via Akt-dependent regulation of FKHRL1. Mol. Biol. Cell. 12: 3328-3339

53. Chua CC, Chua BH, Chen Z, Landy $C$ and Hamdy RC (2002) TGF- $\beta 1$ inhibits multiple caspases induced by TNF- $\alpha$ in murine osteoblastic MC3T3-E1 cells. Biochim. Biophys. Acta 1593: 1-8 